\title{
Advanced Glycation Endproducts in Neurofilament Conglomeration of Motoneurons in Familial and Sporadic Amyotrophic Lateral Sclerosis
}

\author{
Samuel M. Chou, ${ }^{1}$ Helen S. Wang, ${ }^{1}$ Akira Taniguchi, ${ }^{2}$ and \\ Richard Bucala ${ }^{3}$ \\ ${ }^{1}$ F. Norris ALS/MDA Research Center, California Pacific Medical \\ Center, San Francisco, California, U.S.A. \\ ${ }^{2}$ Department of Neurology, Mie University School of Medicine, Tsu \\ City, Japan \\ ${ }^{3}$ Laboratory of Medical Biochemistry, The Picower Institute for \\ Medical Research, Manhasset, New York, U.S.A. \\ Communicated by R. Bucala. Accepted March 3, 1998.
}

\begin{abstract}
Background: Massive neurofilament conglomeration in motor neurons has been described to occur in the early stages of both familial and sporadic amyotrophic lateral sclerosis (ALS). Previously, neurofilament conglomerates were immunolabeled for both superoxide dismutase (SODl) and nitrotyrosine, suggesting the potential for oxidative nitration damage to neurofilament protein by peroxynitrite. Long-lived neurofilaments may also undergo modification by advanced glycation endproducts (AGEs) with concomitant generation of free radicals, including superoxide. This radical species may then react with nitric oxide to form the potent oxidant, peroxynitrite, which in turn can nitrate neurofilament protein. Such a glycated and nitrated neurofilament protein may become resistant to proteolytic systems, forming high-molecular-weight protein complexes and cytotoxic, neuronal inclusions.

Materials and Methods: Paraffin sections containing both neurofilament conglomerates and neuronal inclusions were obtained from patients with sporadic $(n=5)$
\end{abstract}

and familial ( $n=2)$ ALS and were probed with specific antibodies directed against the AGEs cypentodine/piperidine-enolone, arginine-lysine imidazole, pentosidine, and pyrraline.

Results: Neurofilament conglomerates, but not neuronal inclusions, were intensely immunolabeled with each of the anti-AGE antibodies tested. The immunoreactivity was selective for neurofilament conglomerates and suggested that AGEs may form inter- or intramolecular cross-links in neurofilament proteins.

Conclusions: These data support the hypothesis that AGE formation affects neurofilament proteins in vivo and is associated with the concomitant induction of SODl and protein nitration in neurofilament conglomerates. AGE formation in neurofilament protein may not only cause covalent cross-linking but also generate superoxide and block nitric oxide-mediated responses, thereby perpetuating neuronal toxicity in patients with ALS.

\section{Introduction}

The seminal pathologic feature of early amyotrophic lateral sclerosis (ALS), a disease of neuro-

Address correspondence and reprint requests to: Dr. Samuel M. Chou, F. Norris ALS/MDA Research Center, California Pacific Medical Center, 2351 Clay Street, Suite 416, San Francisco, CA 94115, U.S.A. Phone: (415) 923-3607; Fax: (415) 563-7325; E-mail: schou@cooper.cpmc.org filament-rich neurons, is massive neurofilament conglomeration in motor neurons $(1,2)$. The most extreme changes include the formation of axonal spheroids in lower motor neurons and conglomerates in upper motor neurons (3). Both familial and sporadic ALS show these changes on histopathological examination $(2,4,5)$. The study of neurofilament conglomeration is critical for 
Table 1. Antibody immunoreactivities

\begin{tabular}{|c|c|c|c|c|c|c|c|}
\hline Antibody & Source & $\mathbf{m A b} / \mathbf{p A b}$ & Dilution & Axs & Cgl & $\mathbf{M N}$ & HI \\
\hline $\mathrm{Cy} / \mathrm{Pi}^{a}$ & Makita et al. (30) & $\mathrm{mAb}$ & $1: 24,000$ & +3 & +4 & +1 & - \\
\hline Arg-Lys $\operatorname{Imi}^{a}$ & Al-Abed and Bucala (31) & $\mathrm{pAb}$ & $1: 900$ & +3 & +3 & +1 & - \\
\hline Pentosidine & Smith et al. (35) & pAb & $1: 500$ & +2 & +2 & +1 & - \\
\hline Pyrraline & Smith et al. (35) & $\mathrm{mAb}$ & $1: 300$ & +3 & +2 & +1 & - \\
\hline SODl & Sigma & $\mathrm{mAb}$ & $1: 500$ & +3 & +3 & +1 & +1 \\
\hline Ubiquitin & DAKO & $\mathrm{pAb}$ & $1: 50$ & +2 & +1 & - & +4 \\
\hline NF-p & SMI & $\mathrm{mAb}$ & $1: 100$ & +4 & +4 & - & - \\
\hline NF-np & SMI & $\mathrm{mAb}$ & $1: 100$ & +3 & +4 & +2 & +1 \\
\hline NF-L-np & Zymed & $\mathrm{mAb}$ & $1: 50$ & +3 & +4 & +1 & - \\
\hline b-NOS & Affinity & $\mathrm{pAb}$ & $1: 200$ & +1 & +2 & - & +1 \\
\hline Nitrotyrosine & Beckman et al. (9) & $\mathrm{mAb}$ & $1: 40$ & +1 & +2 & +1 & - \\
\hline
\end{tabular}

Axs, axonal spheroids; Cgl, conglomerates; MN, motor neurons; HI, hyaline inclusions; mAb, monoclonal antibody; pAb, polyclonal antibody; NF-p, phosphorylated neurofilament; NF-np, nonphosphorylated neurofilament; NF-L-np, nonphosphorylated neurofilament light-subunit; b-NOS, brain nitric oxide synthease.

${ }^{a}$ The anti-cypentodine/piperidine-enolone ( $\mathrm{Cy} / \mathrm{Pi}$ ) and anti-arginine-lysine imidazole (Arg-Lys Imi) do not react significantly with pyrraline, pentosidine, or carboxylmethyl-lysine.

understanding the pathogenesis of ALS, as various ubiquitin $(+) /$ SOD $1(+)$ neuronal inclusions, such as hyaline, Lewy body-like, or skein-like inclusions, may derive from neurofilament conglomerates (4-7). The discovery of an SODl gene mutation in a small fraction of familial ALS patients (8) has compelled us to examine potential oxidative damage of motor neuron proteins in ALS and to correlate this with reactive oxidative species such as superoxide and nitric oxide. Nitric oxide is believed to be the only biologically derived molecule that can supersede SOD 1 for capture of superoxide, and both tyrosine nitration and metabolites of the nitric oxide/cGMP cascades have been demonstrated in SOD1-positive neurofilament conglomerates (9-12).

Neurofilament aggregation is a chronic process that may also involve the time-dependent cross-linking of neurofilament protein by advanced glycation endproducts (AGEs). In macromolecules such as low-density lipoprotein, AGE formation has been associated with oxidative modification and free radical production in vitro (13-15). Because the neuronal inclusions in ALS have been reported to be immunoreactive for SOD 1 (16-22), nitrotyrosine (11,12,23-26), and ubiquitin $(5,6,27,28)$, we considered the possibility that AGE formation in neurofilament conglomerates or axonal spheroids may play a role in the formation of protein complexes and the resultant neurotoxicity that characterizes ALS.

\section{Materials and Methods}

Brain and spinal cord specimens were obtained from seven ALS patients; (five had a history of sporadic ALS with prominent axonal spheroids and two had familial ALS with scattered conglomerates in the motor cortex) and one normal control. Four segments were obtained from the lumbar spinal cord and the brain sections were obtained from the motor cortex. Tissue was fixed in $10 \%$ formaldehyde, embedded in paraffin, cut at $7 \mu \mathrm{m}$ thickness, and stained with hematoxylin and eosin for confirmation of the presence of neurofilament conglomerates. Immunohistochemical staining was performed by a Ventana automated system (Ventana, Tucson, AZ), applying avidin-biotin complex with 3,3'-diaminobenzidine $(\mathrm{DAB})$ as the chromogen. Paraffin sections were immunostained with antibodies against the AGEs [cypentodine/piperidineenolone (29), arginine-lysine imidazole $(30,31)$, pentosidine, and pyrraline (32)]. The sources and working dilutions of the primary antibodies against AGEs and other antigens are summarized in Table 1. Immunostaining for SOD 1, ubiquitin, and both phosphorylated and nonphosphorylated neurofilament subunits (light, NF-L; medium, NF-M; heavy, NF-H) for confirmation of neurofilament conglomeration was performed as previously reported $(11,12)$. Preabsorption testing for each of the anti-AGE antibodies was per- 
formed as previously described (32-35). Antibody to AGE was incubated with respective antigen, AGE-BSA (bovine serum albumin) for monoclonal and AGE-RNase (ribonuclease) for polyclonal antibody, for $1 \mathrm{hr}$ at $37^{\circ} \mathrm{C}$ at a concentration of $0.5-1 \mathrm{mg} / \mathrm{ml}$. The preabsorbed complexes were removed by centrifugation at top speed for $30 \mathrm{~min}$. The supernatant was applied to the known AGE-positive spinal cord and motor cortex sections and the procedure for immunohistochemistry carried out as usual. Background immunostaining was assessed by omission of the primary antibody as another test for a negative control.

\section{Results}

SODl, ubiquitin, and neurofilament immunoreactivities were co-localized with axonal spheroids and conglomerates as previously reported, along with the metabolites and enzymes related to nitric oxide/cGMP cascades $(11,12)$. Immunoreactivities for all the AGEs tested were unequivocally intense and selective in both axonal spheroids (Fig. la, c) and conglomerates (Fig. lb, d), whereas staining in the perikarya and the neuropil were negligible or equal to that of the background. AGE immunoreactivities in glial cells were also negligible, as were ubiquitin-immunopositive hyaline inclusions. The distribution patterns and immunoreactivities with antibodies against the two different AGEs were similar (Fig. la-d), although the monoclonal antibody against the AGE (cypentidone/piperidineenolone) was most sensitive and selectively immunoreactive for neurofilament conglomerates with little background staining at a $1: 24,000$ dilution. Negative controls for both polyclonal and monoclonal (rabbit IgG and mouse IgG) immunostaining are shown in Figure le and 1f, respectively, after pre-absorption with corresponding antigen. Whereas the immunoreactivities for pyrraline were equally intense and selective for neurofilament conglomerates and axonal spheroids (Fig. 2a, b), those for pentosidine were not as selective as pyrraline (Fig. 2d). Ubiquitin immunoreactivity was most intense in hyaline inclusions (Fig. 2c, arrowhead) and axonal spheroids were modestly immunopositive as well, but the neuronal soma was immunonegative. No AGE immunoreactivity was detected in hyaline or Bunina inclusions. Co-localization of immunoreactivities of AGE with those of neurofilament subunits, especially of the nonphosphory- lated NF-np (Fig. 2e) and NF-L-np (Fig. 2f), was unequivocal. No qualitative difference was noted in the immunoreactivities of axonal spheroids and neurofilament conglomerates between familial and sporadic ALS cases. Although neurofilament conglomerates in Betz cells were far more frequently noted in the familial ALS cases, its sigificance could not be construed because of the small number of cases studied. No neuronal inclusions were encountered in motoneurons of the control case. The rare diffuse intraneuronal neurofilament deposits of aging were infrequently encountered in small cortical pyramidal neurons, but they appeared distinctly different from the conglomerates in ALS patients.

\section{Discussion}

The linkage of the SOD 1 gene mutation to chromosome $21 \mathrm{q} 22$ in a small fraction of patients with familial ALS suggests that aberrant oxidation or free radical production may be involved in the pathogenesis of this disease (8). Oxidative modification of neurofilament protein may also play a role, according to the results of studies of transgenic mouse lines that overexpress human neurofilament subunits, and to data obtained with human SOD 1 mutants in which neurofilament accumulation was observed, as was neuronal cytoskeletalopathy secondary to SOD gained toxicity $(21,36-43)$. In a case of ALS with SOD1-induced toxicity, concurrent neurofilament disruption and accumulation were postulated to be a general mechanism for the pathogenesis of familial ALS (44).

Neurofilaments consist of long-lived cytoskeletal proteins with a slow turnover rate, and both early and late (Maillard) AGEs form in neurofilaments obtained from patients with diabetes mellitus and diabetic polyneuropathy (45-48), normal aging $(32,49)$, and Alzheimer's disease $(35,50)$. Although the particular type of glycation damage affecting neurofilaments has not been well documented, the vulnerability of neurofilaments to modification by the AGEs pyrraline or pentosidine has been suggested as a likely mechanism for producing irreversible, proteinprotein cross-linking $(47,48)$. Neurofilament protein subunits of both $200 \mathrm{kD}(\mathrm{NF}-\mathrm{H})$ and 160 $\mathrm{kD}$ (NF-M) have multiple repeat sequences of KSP (Lys-Ser-Pro) at their carboxyl termini, and these subunits would be potentially susceptible to glycation reactions that affect lysine residues. It is noteworthy that both phosphorylation and 

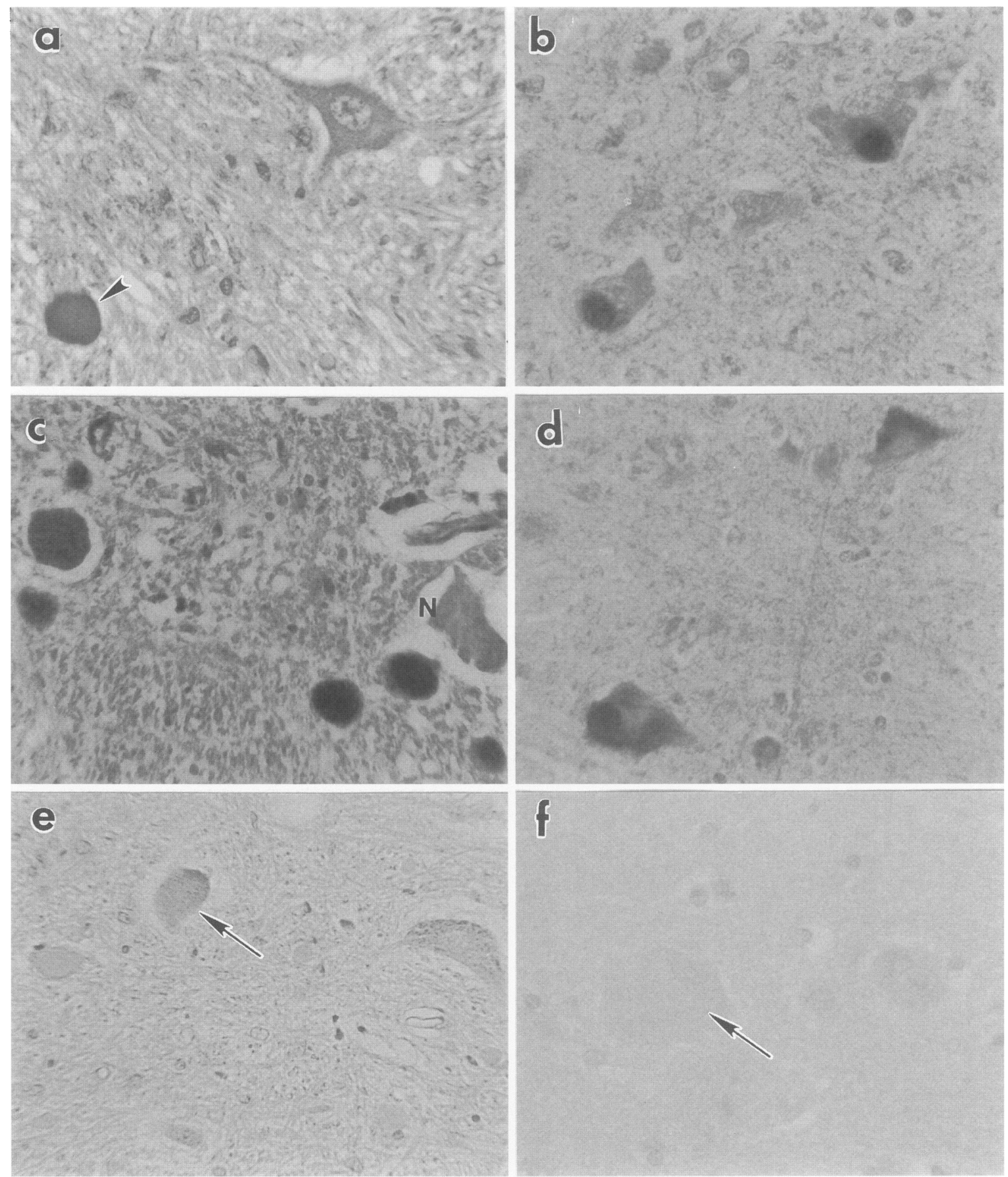

f

Fig. 1. Immunoreactivities for all AGEs tested

in this study. (a) Anterior horn of the lumbar spinal cord of a case of sporadic ALS immunostained with polyclonal antibody against the AGE arg-lys imidazole. The arrowhead shows an immunoreactive axonal spheroid. Light counterstaining is with hematoxylin $(\times 320)$. (b) Two pyramidal neurons in the motor cortex from a case of familial ALS showing spheroidal conglomerates immunostained with polyclonal antibody against arg-lys imidazole $(\times 300)$. (c) Axonal spheroids intensely immunostained with a monoclonal antibody directed against the AGE cy- pentodine/piperidine-enolone. $\mathrm{N}$, neighboring spinal motor neuron $(\times 320)$. (d) Two Betz cells containing conglomerates, immunostained with the anti-cypentodine/piperidine-enolone mAb $(\times 300)$. (e) Faint AGE immunoreactivity in axonal spheroid (arrow) after preabsorption of polyclonal antibody with antigen protein (AGE-RNase) $(\times 300)$. (f) Absence of AGE immunoreactivity in neurofilament conglomerate in a Betz cell (arrow) after preabsorption of monoclonal antibody with the antigen protein (AGE-BSA). $(\times 300)$ 

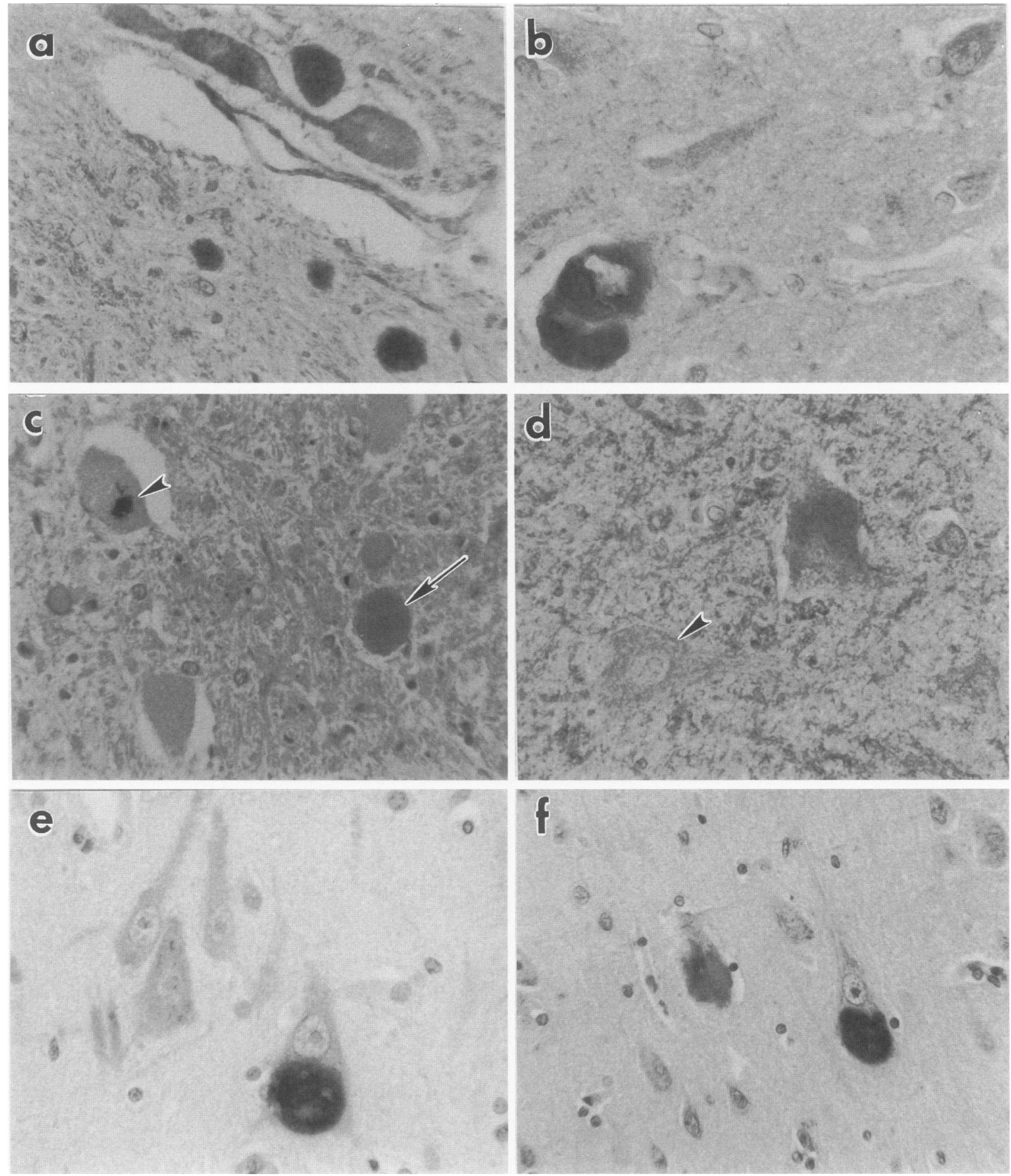

Fig. 2. Immunoreactivities for pyrraline, ubiquitin, pentosidine, and neurofilament subunits. (a) Anterior spinal horn showing scattered axonal spheroids intensely immunostained with anti-pyrraline mAb $(\times 320)$. (b) A markedly swollen and deformed Betz cell with conglomerate strongly immunostained with the anti-pyrraline mAb and negatively immunostained central vacuoles $(\times 400)$. (c) Intensely immunoreactive hyaline inclusion for ubiquitin (arrowhead) in neuron soma which is largely immunonegative and moderately immunopo-

sitive axonal spheroids (arrow) $(\times 300) .(\mathrm{d})$ Betz cell with conglomerate immunostained with an antipentosidine $\mathrm{pAb}$. Note a Betz cell without conglomerate (arrowhead) free of immunoreactivity, serving as internal control $(\times 400)$. (e) A round conglomerate intensely immunostained for nonphosphorylated neurofilament (NF-np) with a few vacuoles in Betz cells of which perikaryon is moderately immunopositive $(\times 400)$. (f) Two Betz cells showing strongly immunopositive conglomerates for nonphosphorylated neurofilament light-subunit (NF-L-np) $(\times 300)$. 
enzymatic glycosylation of serine and threonine residues within the head domain of neurofilament subunits are considered essential for the normal assembly of neurofilaments, and these processes may be disrupted by AGE formation (51-55). AGE-modified proteins also can be degraded to yield reactive, low-molecular-weight AGE peptides that may further contribute to neurofilament damage and conglomeration, which is similar to what has been described for the reaction of AGE peptides with collagen or circulating low-density lipoprotein in vivo $(30,56,57)$.

The present study provides indirect evidence that AGE formation may precede oxidative damage to neurofilament protein causing conglomeration and cross-linking $(53,54)$. Indeed, the intense expression of SODl in neurofilament conglomerates and inclusions suggests that local production of superoxide may occur as a result of the glycation of neurofilament proteins $(11,12,17)$. The production of superoxide and other radicals has been described in vitro in model glycation systems (58). Nitric oxide generation in motor neurons (which normally do not have the active enzyme for synthesizing nitric oxide) can be induced only by injuries such as axonotomy or avulsion (59-61). Nitric oxide is also the only known biological molecule that is sufficiently reactive and produced in high enough local concentrations to compete with SOD 1 for superoxide (9). Peroxynitrite, the reaction product of superoxide and nitric oxide, a potent oxidant, may then further contribute to the post-translational damage of neurofilament proteins. Accordingly, both motor neuron injuries and glycation of neurofilament protein may trigger and perpetuate peroxynitrite toxicity and the irreversible formation of neurofilament conglomerates.

Three post-translational neurofilament protein modifications have thus far been implicated in ALS. They are nitration, hyperphosphorylation, and glycation, all of which have been associated with oxidative damage of neurofilament proteins $(10,47,62)$. Moreover, at least three major cytoplasmic proteolytic systems, balanced by their inhibitors, appear to be involved in the degradation of damaged neurofilament proteins (ubiquitin/ATP-dependent protease, serpin/ serine protease, and cystatin/cysteine protease) $(2,12)$. The activities of these systems overlap one another and are functionally interrelated in vivo. By immunohistochemistry, up-regulation of protein-bound nitrotyrosine was recently demonstrated in the neurofilament conglomerates and axonal spheroids of motor neurons in ALS by labeling with nitrotyrosine antibody $(11,12,23,24)$. Because of the abundance of tyrosine residues, the NF-L subunit may also be vulnerable to nitration by peroxynitrite, which is formed by nitric oxide and superoxide $(9,10)$. Although a recent report (25) indicates that nitrotyrosine formation predominantly affects the free amino acid tyrosine and not tyrosine contained in protein residues, nitrated and glycated peptides may form small soluble "second-generation AGEs" that can further propagate protein and tissue damage $(25,50,56)$.

The formation of AGEs on neurofilament proteins by a direct chemical reaction involving substrates other than reducing sugars cannot be excluded, as pyrraline production or "pyrrolylation" by 2,5 , hexanedione (63) or by $\beta$ - $\beta^{\prime}$-iminodipropionitrile (IDPN) (64) may be possible. AGE formation may also occur, at least in part, after conglomerates form, as these aggregates are long-lived in vivo and may accumulate a variety of secondary modifications over time (30). In the present study, the most consistent and intense signals for AGE immunoreactivity co-localized with axonal spheroids and conglomerates. Investigation of toxic, second-generation AGE-peptides and recently identified AGE-specific receptors, which are abundantly distributed in bovine spinal motor neurons, is also warranted in ALS $(34,56,65,66)$. Structural elucidation of the precise neurofilament modifications present in axonal spheroids and conglomerates may prove to be important in understanding the morphogenesis of the neuronal inclusions that characterize ALS.

\section{Acknowledgments}

The authors gratefully acknowledge the generous contribution of antibodies against pyrraline and pentosidine by Drs. V. Monnier, G. Perry, and $M$. Smith of the Case Western Reserve University, Cleveland, Ohio.

\section{References}

1. Chou SM. (1995) Pathology of motor system disorder. In: Leigh PN, Swash M (eds). Motor Neuron Disease: Biology and Management. Springer-Verlag, London, pp. 53-92.

2. Chou SM. (1997) Neuropathology of amyotrophic lateral sclerosis-new perspectives on an old disease. J. Formos. Med. Assoc. 96: 488-498. 
3. Carpenter S. (1968) Proximal axonal enlargement in motor neuron disease. Neurology 8: 841-851.

4. Chou SM. (1979) Pathognomy of intraneuronal inclusions in ALS. In: Japanese Medical Research Foundation (ed). Amyotrophic Lateral Sclerosis. University of Tokyo Press, Tokyo, pp. 135-176.

5. Murayama SH, Mori, H, Ihara Y, Bouldin TW, Suzuki K, Tomonaga T. (1990) Immunocytochemical and ultrastructural studies of lower motor neurons in amyotrophic lateral sclerosis. Ann. Neurol. 27: 137-148.

6. Leigh PN, Anderson BH, Dodison A, Gallo M, Swash M, Power D. (1992) Ubiquitin deposits in anterior horn cells in motor neuron disease. $\mathrm{Neu}$ rosci. Lett. 93: 197-203.

7. Chou SM. (1994) Accumulation of disassembled neurofilament in upper motor neurons of ALS. In: Rose FC (ed). ALS-From Charcot to the Present and into the Future. Smith-Gordon \& Nishimura Press, London, pp. 167-178.

8. Rosen DR, Siddique T, Patterson D. et al. (1993) Mutations in $\mathrm{Cu} / \mathrm{Zn}$ superoxide dismutase gene are associated with familial amyotrophic lateral sclerosis. Nature 362: 59-62.

9. Beckman JS, Ye YZ, Chen J, Conger KA. (1996) The interactions of nitric oxide with oxygen radicals and scavengers in cerebral ischemic injury. Adv. Neurobiol. 71: 339-351.

10. Beckman JS, Carson M, Smith CD, Koppenol WH. (1993) ALS, SOD, and peroxynitrite. Nature 364: 584-585.

11. Chou SM, Wang HS, Komai K. (1996) Co-localization of SOD-1 and NOS in neurofilament accumulation within motor neurons of amyotrophic lateral sclerosis: An immunohistochemical study. J. Chem. Neuroanat. 10: 249-258.

12. Chou SM, Wang HS, Taniguchi A. (1996) Role of SOD-1 and nitric oxide/cyclic GMP on neurofilament aggregation in ALS/MND. J. Neurol. Sci. 139 (Suppl): 16-26.

13. Fu MX, Requena JR, Jenkins AJ, Lyons TJ, Baynes JW, Thorpe SR. (1996) The advanced glycation end product, N-epsilon-(carboxymethyl)lysine, is a product of both lipid peroxidation and glycoxidation reactions. J. Biol. Chem. 271: 9982-9986.

14. Fu MX, Wells-Knecht KJ, Blackledge JA, Lyons TJ, Thorpe SR, Baynes JW. (1994) Glycation, glycoxidation, and cross-linking of collagen by glucose. Kinetics, mechanisms, and inhibition of late stages of the Maillard reaction. Diabetes 43: 676683.

15. Yim HS, Kang SO, Hah YC, Chok PB, Yim MB. (1995) Free-radicals generated during the glycation reaction of amino acids by methylglyoxal; a model study of protein-cross-linked free radicals. J. Biol. Chem. 270: 28228-28233.

16. Shibata N, Hirano A, Kobayashi M, et al. (1997) Advanced glycosylation end products (AGE) deposition in intraneuronal hyaline inclusions (IHIs) of spinal cords from familial amyotrophic lateral sclerosis (ALS) patients with superoxide dismutase-1 (SOD1) mutation and from transgenic mice expressing mutant human SODl. Brain Pathol. 7: 1073A.

17. Shibata N, Hirano M, Klapporth K. (1993) Immunohistochemical demonstration of $\mathrm{Cu} / \mathrm{Zn}$ superoxide dismutase in the spinal cord of patients with familial amyotrophic lateral sclerosis. Acta Histochem. Cytochem. 26: 619-621.

18. Shibata N, Hirano A, Kobayashi M, Sasaki S, Kato T, Matsumoto S, Shiozawa Z, Komori T, Ikemoto A, Umahara T, et al. (1994) $\mathrm{Cu} / \mathrm{Zn}$ superoxide dismutase-like immunoreactivity in Lewy bodylike inclusions of sporadic amyotrophic lateral sclerosis. Neurosci. Lett. 179: 149-152.

19. Pardo CA, Xu Z, Borchet DR, Price DL, Sisodia SS, Cleveland DW. (1995) Superoxide dismutase is an abundant component in cell bodies, dendrites, and axons of motor neurons and in a subset of other neurons. Proc. Natl. Acad. Sci. U.S.A. 92: 954958.

20. Nishiyama SH, Murayama S, Shimizu J, et al (1995b) $\mathrm{Cu} / \mathrm{Zu}$ superoxide dismutase-like immunoreactivity is present in Lewy bodies from Parkinson's disease: A light and electron microscopic immunocytochemical study. Acta Neuropathol. 89: 471-474.

21. Bruijn LI, Becher MW, Lee MK, Anderson KL, Jenkins NA, Copeland NG, Sisodia SS, Rothstein JD, Borchelt DR, Price DL, Cleveland DW. (1997) ALS-linked SODl mutant G85R mediates damage to astrocytes and promotes rapidly progressive disease with SODl-containing inclusions. Neuron 18: 327-338.

22. Wang HS, Taniguchi A, Chou SM. (1997) Role of SOD1 in nitration of neurofilamentous aggregation induced by IDPN in rats. Ann. Neurol. 43: 415-416A.

23. Abe K, Pan LH, Watanabe M, Konno H, Kato T, Itoyama Y. (1997) Upregulation of protein-tyrosine nitration in the anterior horn cells of amyotrophic lateral sclerosis. Neurol. Res. 19: 124-128.

24. Beal MF, Ferrante RJ, Browne SE, Matthews RT, Kowall NW, Brown RH Jr. (1997) Increased 3-nitrotyrosine in both sporadic and familial amyotrophic lateral sclerosis. Ann. Neurol. 42: 646-654.

25. Bruijn LI, Beal MF, Becher MW, Schulz JB, Wong PC, Price DL, Cleveland DW. (1997) Elevated free nitrotyrosine levels, but not protein-bound nitrotyrosine or hydroxyl radicals, throughout amyotrophic lateral sclerosis (ALS)-like disease implicated tyrosine nitration as an aberrant in vivo property of one familial ALS-linked superoxide dismutase 1 mutant. Proc. Natl. Acad. Sci. U.S.A. 94: 7606-7611.

26. Delanty N, Prezedborski S, Bandele AN, Lynch T, Rosario R. (1997) Elevated nitrotyrosine immunoreactivity in patients with amyotrophic lateral sclerosis. Ann. Neurol. 42: 427A.

27. Schiffer D, Autilio-Gambetti L, Chio A, Migheli A, 
Pezzulo T. (1991) Ubiquitin in motor neuron disease: A study at the light and electron microscopic level. J. Neuropathol. Exp. Neurol. 50: 463-473.

28. Migheli A, Attanasio A, Schiffer D. (1994) Ubiquitin and neurofilament expression in anterior horn cells in amyotrophic lateral sclerosis: Possible clues to the pathogenesis. Neuropathol. Appl. Neurobiol. 20: 282-289.

29. Zhang X, Mitsuhashi T, Pan S, Bucala R, Ulrich P. (1997) Two cyclic AGEs from dehydration of the Amadori product are recognized by polyclonal and monoclonal antibodies to AGEs. Diabetes 46 (Suppl 1): A0598.

30. Makita Z, Bucala R, Rayfield EJ, Friedman EA, Kaufman AM, Korbert SM, Barth RH, Winston JA, Fuh H, Manogue KR, et al. (1994) Reactive glycosylation endproducts in diabetic uremia $\&$ treatment of renal failure. Lancet 343: 1519-1522.

31. Al-Abed Y, Bucala, R. (1997) A novel AGE crosslink that exhibits immunological crossreactivity with in vivo-formed AGEs. Diabetes 46: (Suppl 1): A0271.

32. Monnier VM, Sell DR, Ramanakoppa $\mathrm{H}$, et al. (1992) Maillard reaction-mediated molecular damage to extracellular matrix and other tissue proteins in diabetes, aging, and uremia. Diabetes 41 (Suppl 20: $36-41$.

33. Nakamura Y, Horii Y, Nishino T, et al. (1993) Immunohistochemical localization of advanced glycosylation endproducts (AGEs) in coronary atheroma and cardiac tissue in diabetes mellitus. Am. J. Pathol. 143: 1649-1656.

34. Stitt A, Li YM, Gardiner TA, Bucala R, Archer D, Vlassara H. (1997) Advanced glycation end products (AGEs) co-localized with AGE receptors in the retinal vasculature of diabetic and of AGEinfused rats. Am. J. Pathol. 150: 523-531.

35. Smith MA, Taneda S, Richey PL, Miyata S, Yan SD, Stern D, Sayre LM, Monnier VM, Perry G. (1994) Advanced Maillard reaction end products are associated with Alzheimer disease pathology. Proc. Natl. Acad. Sci. U.S.A. 91: 5710-5714.

36. Xu Z, Cork LC, Griffin JW, Cleveland DW. (1993) Increased expression of neurofilament subunit NF-L produces morphological alterations that resemble the pathology of human motor neuron disease. Cell 73: 23-33.

37. Lee MK, Marszalek JR, Cleveland DW. (1994) A mutant neurofilament subunit causes massive, selective motor neuron death: Implication for the pathogenesis of human motor neuron disease. Neuron 13: 975-988.

38. Ma D, Descarries L, Julien JP, Doucet G. (1995) Abnormal perikaryal accumulation of neurofilament light protein in the brain of mice transgenic for the human protein sequence of postnatal development. Neuroscience 68: 135-149.

39. Collard JF, Côté F, Julien JP. (1995) Defective axonal transport in a transgenic mouse model of amyotrophic lateral sclerosis Nature 375: 61-64.
40. Côté F, Collard JF, Houle D, Julien JP. (1994) Copy-dependent and correct developmental expression of the human neurofilament heavy gene in transgenic mice. Brain Res. Mol. Brain Res. 26: 99-105.

41. Del Canto MC, Gurney ME. (1994) Development of central nervous system pathology in a mouse transgenic model of human amyotrophic lateral sclerosis. Am. J. Pathol. 145: 1271-1280.

42. Julien JP, Côté F, Collard JF. (1995) Mice overexpressing the human neurofilament heavy gene as a model of ALS. Neurobiol. Aging 16: 487-490.

43. Tu PH, Raju P, Robinson KA, Gurney ME, Trojanowski JQ, Lee VM. (1996) Transgenic mice carrying a human mutant superoxide dismutase transgene develop neuronal cytoskeletal pathology resembling human amyotrophic lateral sclerosis lesions. Proc. Natl. Acad. Sci. U.S.A. 93: 31553160.

44. Rouleau GA, Clark AW, Rooke K, Pramatarova A, Krizus A, Suchowersky O, Julen JP, Figlewicz D. (1996) SODl mutation is associated with accumulation of neurofilaments in amyotrophic lateral sclerosis. Ann. Neurol. 39: 128-131.

45. McLean WG, Pekiner C, Cullum NA, Casson IF. (1992) Post-translational modifications of nerve cytoskeletal proteins in experimental diabetes. Mol. Neurobiol. 6: 225-237.

46. Yagihashi S. (1993) Axonal cytoskeleton and diabetic neuropathy. Diabet. Med. Suppl. 2: 107S109S.

47. Ryle C, Donaghy M. (1995) Non-enzymatic glycation of peripheral nerve proteins in human diabetics. J. Neurol. Sci. 129: 62-68.

48. Ryle C, Leow CK, Donaghy M. (1997) Nonenzymatic glycation of peripheral and central nervous system proteins in experimental diabetes mellitus. Muscle Nerve 20: 577-584.

49. Vlassara H, Bucala R, Striker L. (1994) Pathogenic effects of advanced glycosylation: Biochemical, biologic, and clinical implications for diabetes and aging. J. Lab. Invest. 70: 138-151.

50. Smith MA, Richey PL, Harris R, Sayre LM, Beckman JS, Perry G. (1997) Widespread peroxynitrite-mediate damage in Alzheimer's disease. J. Neurosci. 17: 2653-2657.

51. Dong D, Xu Z, Chevrier M, Cotter R, Cleveland D, Hart G. (1993) Glycosylation of mammalian neurofilaments. Localization of mutiple O-linked $\mathrm{N}$ acetylglucosamine moieties on neurofilament polypeptides L and M. J. Biol. Chem. 268: 1667916687.

52. Dong D, Xu Z, Hart G, Cleveland D. (1996) Cytoplasmic O-GlcNAc modification of the head domain and the KSP repeat motif of the neurofilament protein neurofilament-H. J. Biol. Chem. 271: 20845-20852.

53. Bucala R. (1996) Laboratory evaluation of advanced glycosylation end products: Relevance to 
diabetes, aging and renal failure. Diagn. Endocrinol. Metab. 14: 99-106.

54. Zhang X, Ulrich P. (1996) Directed approaches to reactive Maillard intermediates: Formation of a novel 3-alkylamineo-2-hydroxy-4-hydroxymethyl-2-cyclopenten-1-one ("Cypentodine"). Tetrahedron Lett. 37: 4667-4670.

55. Hart GW, Greis KD, Dong LY, Blomberg MA, Chou TY, Jiang MS, Roquemore EP, Snow DM, Kreppel LK, Cole RN. (1995) O-linked $N$-acetylglucosamine: The "yin-yang" of Ser/Thr phosphorylation? Nuclear and cytoplasmic glycosylation. Adv. Exp. Med. Biol. 376: 115-123.

56. Vlassara H. (1997) Recent progress in advanced glycation end products and diabetic complications. Diabetes 46 (Suppl 2): S19-25.

57. Bucala R. (1996) Lipid and lipoprotein oxidation: Basic mechanisms and unsolved questions in vivo. Redox Rep. 2: 291-307.

58. Yim H-S, Kang S-O, Hah Y-C, Chock PB, Yim, MB. (1995) Free radicals generated during the glycation reaction of amino acids and methylglyoxal J. Biol. Chem. 270: 28228-28233.

59. Yu WH. (1994) Nitric oxide synthase in motor neurons after axotomy. J. Histochem. Cytochem. 42: 451-457.

60. Wu W. (1993) Expression of nitric-oxide synthase (NOS) in injured CNS neurons as shown by NADPH diaphorase histochemistry. Exp. Neurol. 120: 153-159.

61. Wu Y, Li Y, Liu H, Wu W. (1995) Induction of nitric oxide synthase and motoneuron death in newborn and early postnatal rats following spinal root avulsion. Neurosci. Lett. 194: 109-112.

62. Gou JP, Eyer J, Leterrier JF. (1995) Progressive hyperphosphorylation of neurofilament heavy subunits with aging: Possible involvement in the mechanism of neurofilament accumulation. Biochem. Biophys. Res. Commun. 215: 368-376.

63. Zhu M, Spink D, Yan B, Bank S, DeCaprio A. (1994) Formation and structure of cross-linking and monomeric pyrrole autoxidation products in 2,5-hexanedione-treated amino acids, peptides, and protein. Chem. Res. Toxicol. 7 (Suppl 4): 551558.

64. Chou SM, Wang HS, Taniguchi A. (1996) Does nonenzymatic glycation influence neurofilamentous aggregation in motor neurons? An experimental study. Presented at the 9th AOCN (Asian Oceanic Congress of Neurology) September 5 , Seoul, Korea. Abstract pp97.

65. Brett J, Schmidt AM, Yan SD, et al. (1993) Survey of the distribution of a newly characterized receptor for advanced glycation end products in tissues. Am. J. Pathol. 143: 1699-1712.

66. Schmidt AM, Hori O, Brett J, Yan S-D, Wautier J-L, Stern D. (1994) Cellular receptors for advanced glycation endproducts. Implications for induction of oxidant stress and cellular dysfunction in the pathogenesis of vascular lesions. Arterioscler. Thromb. 14: 1521-1528. 